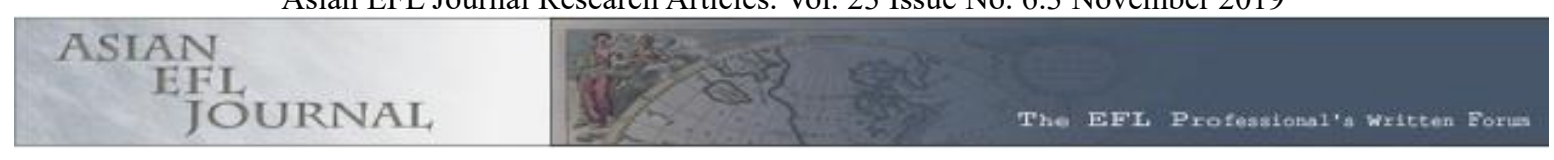

\title{
WhatsApp Audio and Video Chat-Based in Stimulating Students' Self-Confidence and Motivation to Speak English
}

\author{
Authors \\ ${ }^{1}$ Maulina, ${ }^{2}$ Nurdin Noni, ${ }^{3}$ Muhammad Basri \\ ${ }^{1}$ English Lecturer at Muhammadiyah University of Kendari, Indonesia \\ ${ }^{2 \& 3}$ English Lecturer at State University of Makassar, Indonesia
}

Corresponding author: lina821431@yahoo.com

\section{Bio-profiles:}

Maulina is currently a lecturer in English Education Study Program at Muhammadiyah University of Kendari. She is also completing her $\mathrm{PhD}$ in English Education at State University of Makassar. Her research interests include materials development, EFL teaching methodologies, and the use of new technology in foreign language teaching. Her email is lina821431@yahoo.com

Nurdin Noni is a Professor in the English Education Study Program at State University of Makassar. He teaches courses related to Information and Communication of Technology (ICT) in English as a foreign language teaching. His main research is ICT in EFL teaching. His email is nurdinnoni@yahoo.com

Muhammad Basri is a Professor in the English Education Study Program at State University of Makassar. He teaches courses related to English skills. His research interests include materials development, multimedia learning materials in teaching English speaking, and applied linguistics. His email is muhammadbasri@unm.ac.id

\footnotetext{
Abstract

This era of 4.0 industrial revolutions, lecturers, especially English lecturers have to be aware with the technology particularly mobile technology that can enhance their students' English skills in utilizing social media such as WhatsApp to improve students' English
} 
speaking ability in order that they can show high self-confidence and motivation to learn this international language. This research aimed at describing students' day to day English speaking skills via WhatsApp group set as a platform for audio and video chat-based for a semester period. Through these chat-based, students were expected to solve problems in terms of selfconfidence and motivation to speak English. Data was gathered in the form of group WhatsApp day to day observation and close-ended questionnaire with 27 participants selected purposively. These data were analyzed descriptively. The results showed that students felt very confidence and were encouraged to speak through WhatsApp group by audio and video recording chat-based from day to day speaking habit. WhatsApp as a social media has much potential for students to improve their speaking skill through audio and video recording. Therefore, the passive students were also engaged actively when there was a stimulus set by the lecturer and rest members in the WhatsApp group.

Keywords: WhatsApp, audio and video recording chat-based, social media, self-confidence, motivation

\section{Introduction}

The ability to speak English in this era 4.0 industrial revolution using mobile technologies is essential to follow the development around the globe. Mobile technologies offer new educational opportunities more choice for students to access course content, as well as interact with the lecturer and student colleagues wherever and whenever (Beckmann, 2010; Husbye \& Elsener, 2014; Andrews et al. 2015; Bocconi \& Trentin, 2015; Ma, 2017). The interactions are more accessible by using mobile technologies in the form of social media that allow communication and enhance EFL learning (Rodriguez, 2011). One of the most popular social media used today is WhatsApp (Awada \& Wang, 2016; Afful \& Akrong, 2019; Andujar \& Salaberri-Ramiro, 2019)). Since all participants of this study had WhatsApp application in their mobile phones, mobile instant messaging in the form of audio and video chat-based support in this study is solely referred to utilize WhatsApp as social media in day to day learning speaking English to engage students more active with high self-confidence and motivation. Maming (2018) stated that social media is able to motivate students to develop their language skills particularly in reading skills in natural way during the interaction (p. 210). It is in line with Sakkir (2018) who said that students showed high interest in using social media 
in writing skills. In learning speaking, motivation is one crucial aspect to influence students to speak English (Tài, 2016, p. 177-182).

Some studies using WhatsApp in EFL teaching and learning conducted, for instance, language learning (Zhang, Song, \& Burston, 2011) writing proficiency and perceptions (Awada \& Wang, 2016), academic performance (Afful \& Akrong, 2019), international distance education (Madge, et al. 2019), peer tutoring (Timmis, 2012; Campbell, 2019) and more. However, there is little applied research into how WhatsApp used at the university level via a chat-based that support students' day to day speaking performance to stimulate self-confidence and motivation.

This study was to explore the use of WhatsApp recording chat-based in EFL teaching and learning result a contribution to the effective implementation of mobile learning for increasing students' self-confidence and motivation in higher education. The intention of this study was not to conduct the entire speaking course within the WhatsApp. Instead, face-to-face lectures supplemented with the delivery of activities and instructional materials uploaded, learned, and discussed via audio and video recording through WhatsApp outside of the class hours, which observed day to day in a semester. WhatsApp used to strengthen the concept of teaching and to learn in the class and provided students with a real connection, collaboration, and communication between lecturer and classmates. The primary research questions of this study were, "How are students' self-confidence and motivation in day to day speaking English performances in a semester using WhatsApp?"

\section{Literature Review}

This study centers on the use of WhatsApp chat-based as a day to day oral communication platform for engaging students' self-confidence and motivation to speak English. Relevant literature presented as follows: (a) mobile learning, (b) related studies on WhatsApp in EFL teaching and learning, and (c) related studies on self-confidence and motivation with mobile learning integration.

\subsection{Mobile learning}

Mobile learning can make a concept of learning wherever and whenever into a reality. Mobile learning promises to transform the world of learning and leads to solve the narrow limits of the classroom to achieve ubiquitous learning (Simone \& Cosimo, 2016). Boyinbode, Bagula, \& Ngambi (2011) stated that mobile devices enable learning to be carried out in a spontaneous, pervasive, and ubiquitous education process. EFL learning also benefits from 
such opportunities. EFL students get more opportunities to practice their English skills such as listening, speaking, reading, and writing, as well as other sub-skills, for instance, vocabulary and pronunciation (Stockwell, 2010; Sweeney \& Moore, 2012; Fuente, 2014). According to Godwin-Jones (2017) discovered that mobile learning might be a potential motivator; for instance, Zou \& Yan (2014) found that students in other areas of their research have high motivation, and some others have low motivation due to the relative economic development in different cities. Despite, Kim et al. (2013) argued that mobile technologies enable to motivate innovation in English learning and assist educators to realize their pedagogical goals for teaching more effectively. These authors also said that mobile devices functioned as entertainment and communication. A social communication app used in the smartphones found to increase students' positive attitudes towards learning and teachers' feedback that the purpose is for communicative purposes in foreign language learning ( $\mathrm{Xu} \& \mathrm{Peng}$, 2017). Mobile learning is, however, not an opportunity to replace classroom teaching but an additional learning aid that students can use to enhance their learning.

\subsection{Studies on WhatsApp in EFL teaching and learning}

Based on the number of monthly active users (in millions), WhatsApp is the most popular global mobile messenger apps today (Statista, 2019). WhatsApp is considered as a potential medium to support teaching and learning. Also, the familiarity of the use of WhatsApp attracted some researchers to research the use of WhatsApp in EFL teaching and learning.

A study conducted in South African university by Rambe and Bere (2013) did a case study and explored the use of WhatsApp among the undergraduates and reported that WhatsApp has the potential to create a dialogic situation for students' engagement to collaborate as well as to transform teaching and learning. Awada \& Wang (2016) found that the use of WhatsApp in teaching and learning writing was more effective than the regular instruction, and students were motivated to study. Similarly, a study conducted at a university in the central-north of Saudi Arabia by Alshammari et al. (2016) who stated that WhatsApp in EFL instruction encourage autonomously and peer learning and develop learning communities. WhatsApp can support spontaneous communication, the exchange of images, and the sharing of captured video clips in teaching and learning activities. The mobile connectivity and instantaneous services provide an opportunity to offer new ways of teaching and learning that can ultimately improve performance. On-demand access to media content is beneficial to busy and independent learners. 
Plana et al. (2013) reported that students received WhatsApp positively in particular with high levels of satisfaction with language activities sing this application, as well as high levels of motivation to participate in activities that exploit WhatsApp's collaborative potential (Castrillo et al., 2014). Importantly, engaging students in WhatsApp mediated language activities also has a positive impact on their confidence, increasing their reading habits, and willingness to read more in English (Plana, et al., 2013). By allowing learners to select their needed learning materials, this can cultivate a responsive pedagogy for individual differences. WhatsApp is a suitable tool to facilitate this form of learning. WhatsApp allows the teacher to deliver learning materials in small chunks. This method of presenting information is less overwhelming for the learners and makes it easier for their learning. It can also be well-suited for students with a busy lifestyle. WhatsApp also retains the chat history chronologically. The stored Bite-sized materials were in the learner's device for easy access. Learners can conveniently revisit these materials at their own pace and time.

Almost all study-findings supported using WhatsApp to enhance students learning and enthusiasm, using WhatsApp helped students to develop English skills, enriched their vocabulary, and learn from their mates' mistakes (Hamad, 2017). However, little research did on how students day to day interaction, connection, and collaboration using WhatsApp recording chat-based to solve their problem in the aspect of self-confidence and motivation to speak English.

\subsection{Studies on self-confidence and motivation with mobile learning integration}

Li et al. (2018) showed that students were relatively had a high motivation for performing tasks using mobile learning. Also, students showed better performance, and specifically, their intrinsic motivation enhanced after practicing the learning. Comparing the effectiveness of mobile learning tools with conventional learning tools, mobile devices used was reported that the convenient functions could create more interesting learning environments and promote students' motivation (Huang, Yang, Chiang, and Su, 2016). It needs a serious effort to engage students with learning activities in integrating mobile learning in EFL teaching and learning, especially for improving students' self-confidence and motivation. Intrinsic and extrinsic motivation were possible factors to consider to improve. In relation to integrating mobile learning to stimulate students' self-confidence and motivation in learning, Barger and Karabenik (2011) and Shia (2014) pointed out that self-confidence refers to the ability of someone in self-monitoring and self-evaluating, while, motivation is divided into two aspects namely intrinsic and extrinsic. Intrinsic motivation covers the aspect of mastery goal, need for 
achievement, and fear. Further, extrinsic motivation includes authority expectations both to peers and the lecturer.

\section{Research Method}

\subsection{Research Design}

The goal of this research was to explore students' day to day performances in speaking English through WhatsApp audio and video chat-based. A mixed-method approach was selected to explore the implementation of every day WhatsApp chat-based (Johnson, Onwuegbuzie, \& Turner, 2007). Qualitative analysis implemented was in natural daily observation, which was summed up weekly for a semester of teaching and learning that was screenshots in the WhatsApp group, as well as a detailed analysis of connection, communication, and collaboration that occurred in speaking chat-based. Quantitative data examined was in the form of a Google Form survey of using WhatsApp to enhance selfconfidence and motivation.

Talk Time of Everyday English Conversation Book 1 used purposively as the primary material uploaded in the WhatsApp group in order that students were able to access anytime and anywhere they would like to practice conversations assigned. This book also was chosen as topics in line with the Basic Speaking syllabus of the English Department, as well as English conversation designed for pre-intermediate for the university level. Besides, activities designed met the affordances that WhatsApp had for audio and video chat-based. Therefore, students could improve their speaking skills with and without lecturer instructions to record their voice and video recording for feedback from WhatsApp group members.

\subsection{Participant}

Participants were students of the English Department at one of Islamic University in eastern Indonesia. Students were recruited from one class of Basic Speaking class in the second semester of a four-year program in the academic year 2018-2019. Participation was voluntary in this study. Students signed a form and told that they could withdraw from the study at any time without penalty. These students had full time learning to enroll a semester for Basic Speaking lesson. The participant was chosen purposively, which consisted of 25 students aged from 18 to 20 years in which 22 students were Indonesian, and three students were Thai. The majority of the participant in this study was female. 


\section{Table 1}

Participant

\begin{tabular}{|c|c|c|c|c|}
\hline No & Information & Answer & Frequency & Percentage \\
\hline \multirow[t]{3}{*}{1} & Age & 18 & 4 & 16 \\
\hline & & 19 & 13 & 52 \\
\hline & & 20 & 8 & 32 \\
\hline \multirow[t]{2}{*}{2} & Gender & Male & 1 & 4 \\
\hline & & Female & 23 & 96 \\
\hline \multirow[t]{2}{*}{3} & Nationality & Indonesia & 22 & 88 \\
\hline & & Thailand & 3 & 12 \\
\hline
\end{tabular}

\subsection{Research Instrument}

Students' self-confidence and motivation were categorized as very poor (1), poor (2), good (3), and very good (4). Every day speaking activities in the WhatsApp was also screenshots. In addition, validated 31 Likert scale items questionnaire adopted from Barger and Karabenik (2011) and Shia (2014) contained in surveying students' motivation and selfconfidence in speaking English using WhatsApp chat-based were used. Cronbach's alpha of questionnaire validity was 0.94 , which was a high degree level, and it indicated that the adapted questionnaire was suitable to use in this study. Twenty-three items measuring motivation; 17 items intrinsic motivation (mastery goal, need for achievement, and fear) and six items extrinsic motivation (authority expectation both to peers and lecturer). The other eight items were measuring self-confidence (self-monitoring and self-evaluation).

\subsection{Data collection and Analysis}

The observation was conducted to figure out students' day to day interaction of daily conversation in the WhatsApp via recording chat-based, an observation was conducted. There were five (5) college hours from Monday to Friday observation through WhatsApp conducted beyond the class hours. Students were told to record as much as possible their voice and could upload video recordings to support the evidence. The topic of the week was based on the syllabus of the semester lesson — responses given by WhatsApp group members. Students' audio and video recording chat-based were counted and were assessed based on the ability to self-monitoring and self-evaluation. Speaking components and aspects such as pronunciation, intonation, gesture, eye contact in audio and video recording chat-based were considered. In relation with motivation, the number of audio and video recording produced every day were counted to measure students' intention to speak English and to confirmed that they master the 
topic and need a speaking improvement as well as fear of not following the conversation. These observations were triangulated with a questionnaire on the google Form distributed. Students filled out the questionnaire by clicking the link shared in the WhatsApp group of Basic Speaking. Data of the questionnaire were automatically displayed in the form of frequencies and percentages.

\section{Findings and Discussion}

\subsection{Observation}

Observation through WhatsApp started from meeting one of the lessons until the last meeting consisted of 14 meetings, excluded mid-term tests, and final-term tests. A semester observation consisted of four months of the academic period. WhatsApp group was created, and students were told to record their voice and video record as well as to respond to each other every day.

\section{Figure 1}

WhatsApp group

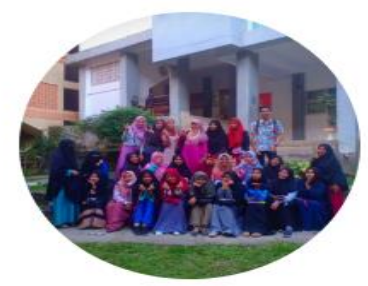

Basic Speaking C

Created 3/25/2019 at 10:16

Students showed intensive ways of stating their thoughts. It seemed from the first week of giving the task to record their voice and video record themselves to show a new way of the idea for the rest WhatsApp members to give responses. Some pauses and short statements were also uttered in the first to three weeks. Then, they tried to lengthen the sentences and actively responding to the topic assigned of the week. 


\section{Figure 2}

\section{Audio recording chat-based}

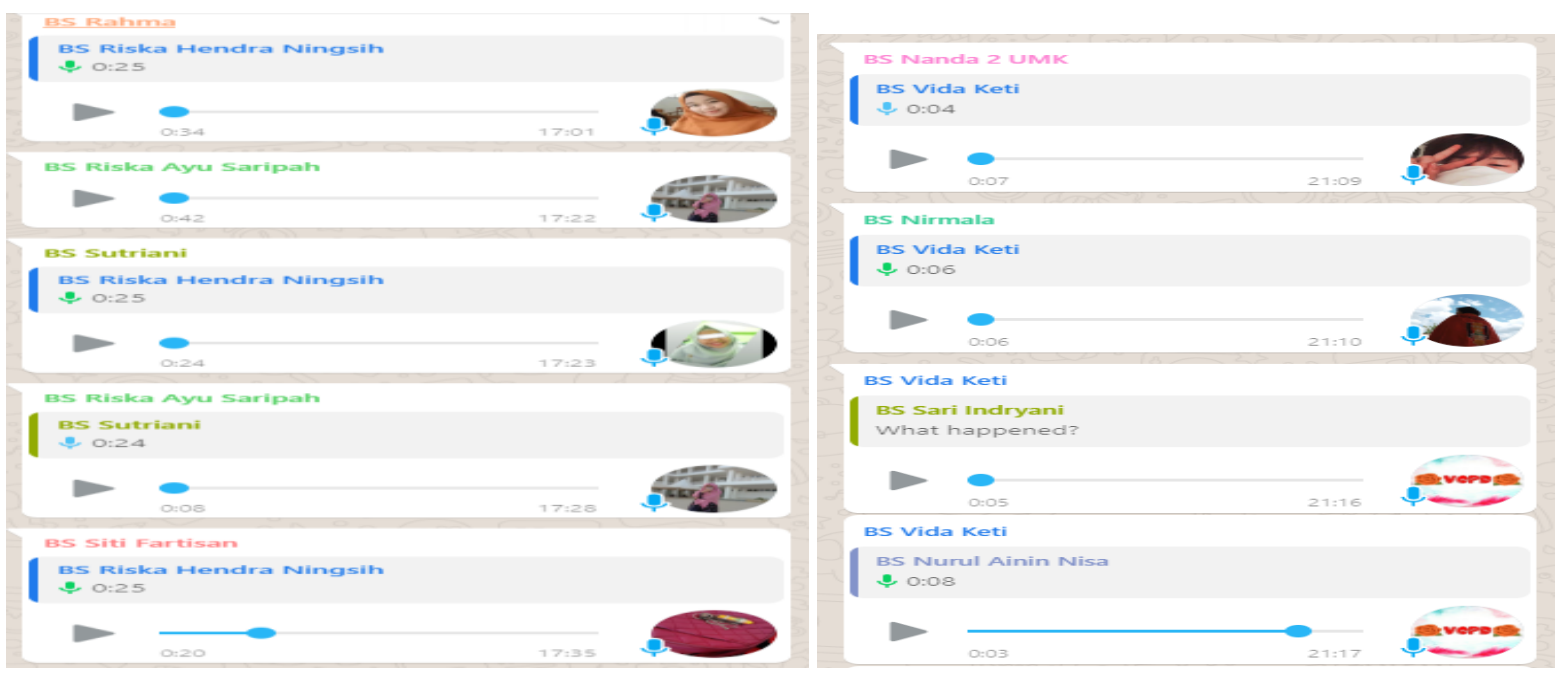

\section{Figure 2}

\section{Video recording chat-based}
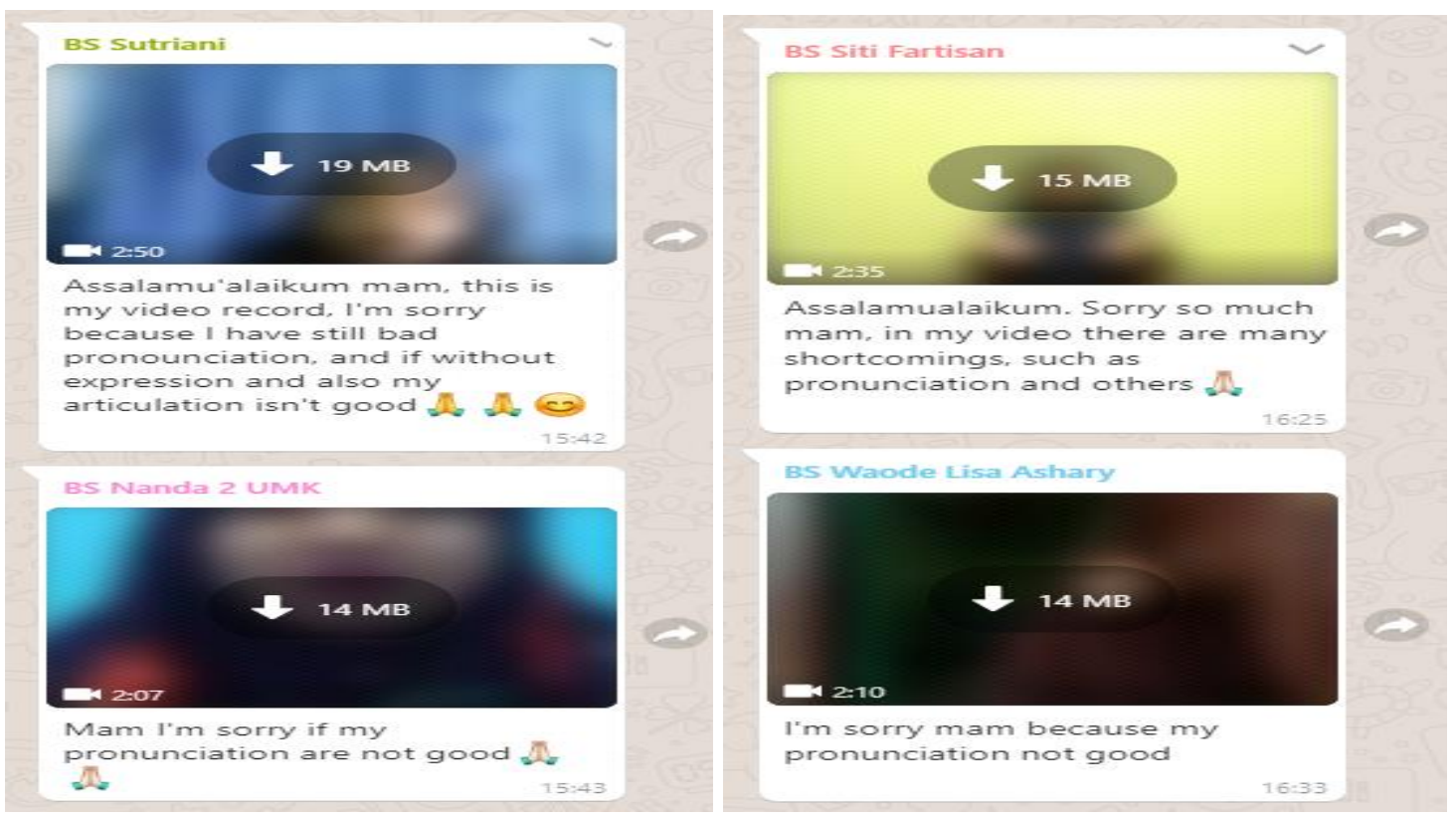

Week one, until week three, students realized that they made some mistakes in terms of mispronouncing words, flat in expressing statements and responses. As a result, they found themselves with no gestures and lack of eye contact in front of their smartphone camera. They further realized and tried to do self-correction, and finally, they made significant progress in doing everyday communication in the WhatsApp group. 


\section{Figure 3}

Lecturerfeedback

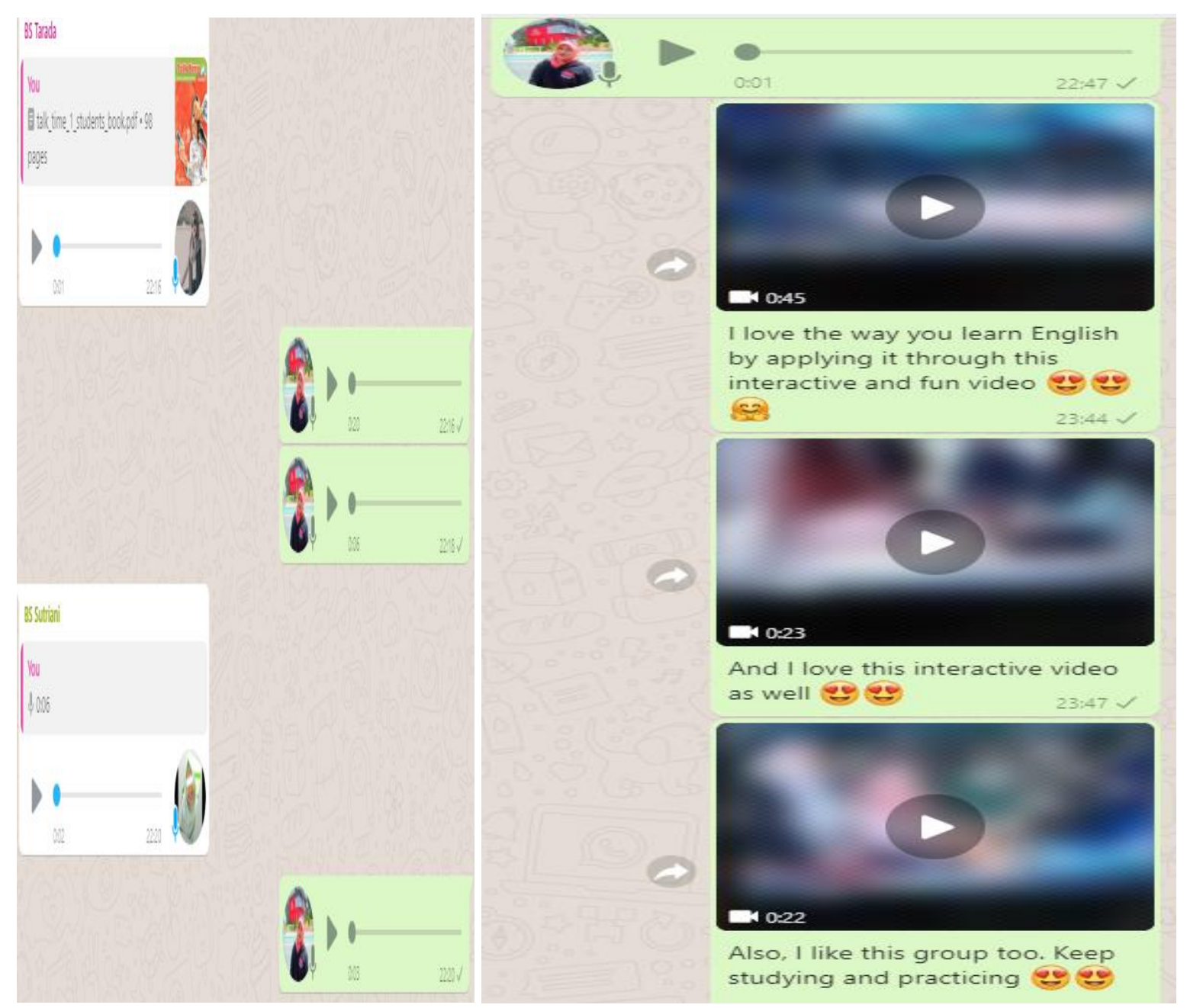

Lecturer, as well as a part of the WhatsApp group member, showed the role of motivator, facilitator, and self-confidence builder. Lecturer allowed more chances for students to get in touch actively in daily conversation. Therefore, students felt no doubt about speaking. 


\section{Chart 1}

\section{Self-confidence}

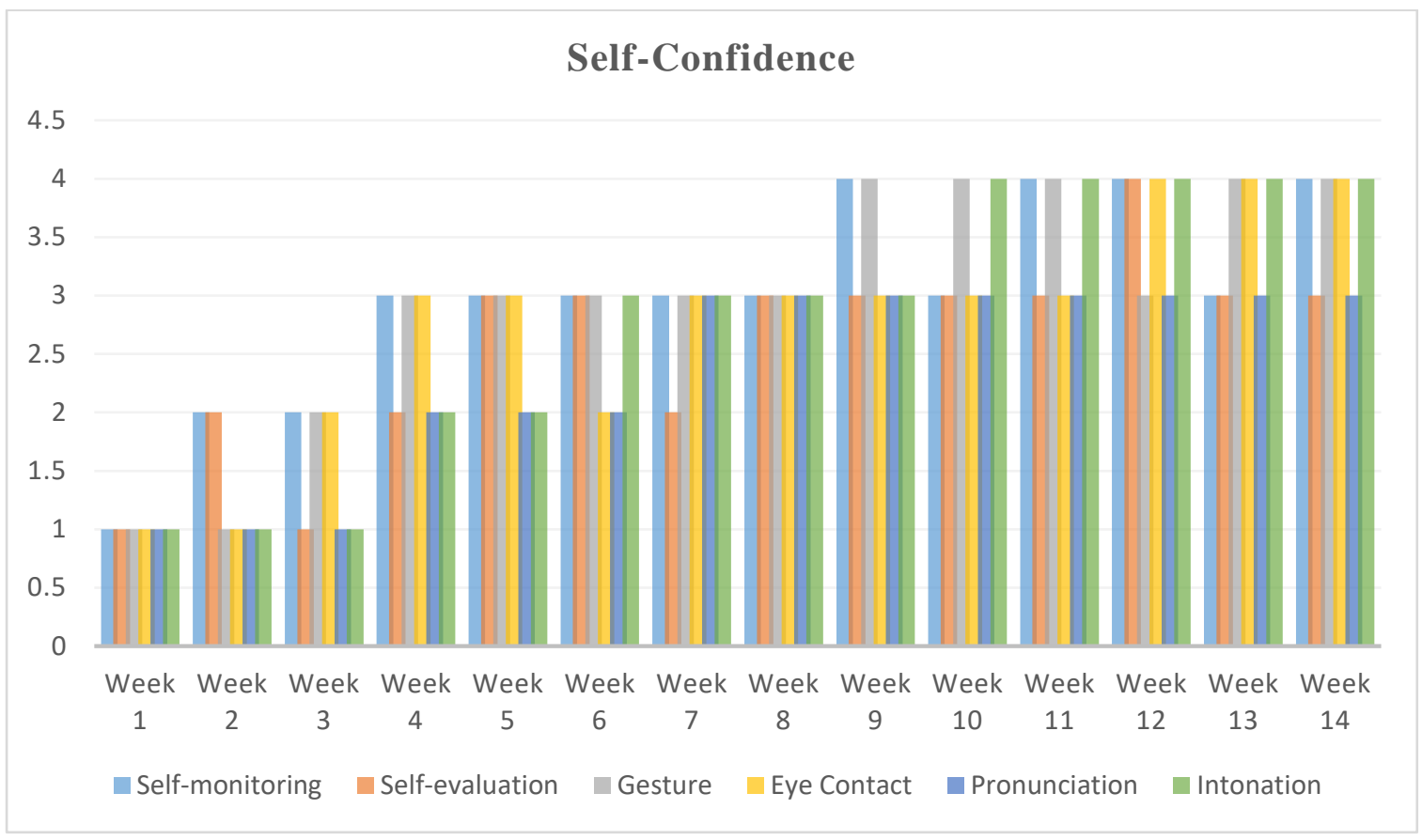

Chart 1 demonstrates students' self-confidence in speaking English through WhatsApp chat-based from week one until week 14. Six aspects of self-confidence were measured weekly. It can be seen that the self-monitoring aspect was relatively low from week 1 to week 3 . However, students started to figure out the importance of the ability to monitor their own speaking performance in week four until week eight as well as they tended to show high selfmonitoring in week nine until week 14. Besides, from the aspect of self-evaluation, students were not really able to evaluate their speaking strengths and weaknesses in the first week, but they started to notice on how to maximize their ability to correct the mistakes such as in choosing word choice and grammar during communicating in the WhatsApp group in week 5 until week 14. The other four aspects, such as gesture, pronunciation, eye contact, and intonation, were roughly similar in progress from week 1 to week 14 . In summary, students found themselves more confidence in asking and responding to a discussion in WhatsApp chatbased. 


\section{Chart 2}

\section{Motivation}

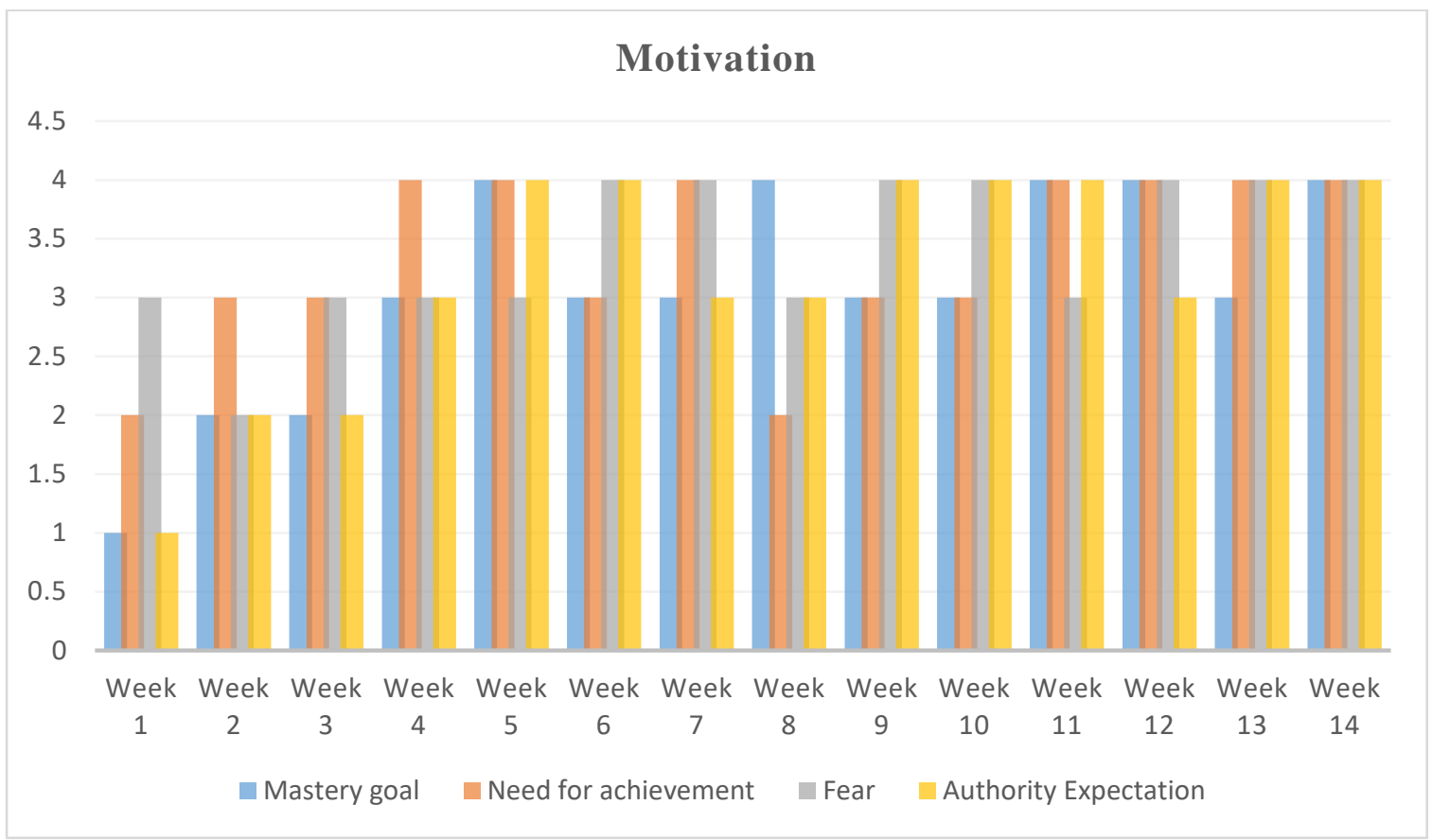

Students' motivation were assessed based on their everyday number of audio and video recording they produced in the WhatsApp group. Intrinsic motivation covers three aspects measured, such as mastery goal, need for achievement, and fear. Besides, extrinsic motivation covers one aspect, namely authority expectation towards peers and lecturer in speaking daily conversation in the WhatsApp. As showed in everyday log observation, both students' intrinsic and extrinsic motivation increased weekly.

\subsection{Questionnaire}

Data in this questionnaire supported the observation.

Table 2

Motivation (Need)

\begin{tabular}{|c|c|c|c|c|}
\hline No & Information & Answer & Frequency & Percentage \\
\hline 1 & $\begin{array}{l}\text { I feel good when } \\
\text { speaking English } \\
\text { through audio and } \\
\text { video recording in the } \\
\text { WhatsApp group }\end{array}$ & $\begin{array}{l}\text { Strongly agree } \\
\text { Agree } \\
\text { Neutral }\end{array}$ & $\begin{array}{l}8 \\
16 \\
1\end{array}$ & $\begin{array}{l}32 \\
64 \\
4\end{array}$ \\
\hline 2 & $\begin{array}{l}\text { I need to practice } \\
\text { speaking English as } \\
\text { much as possible } \\
\text { everyday by audio }\end{array}$ & $\begin{array}{l}\text { Strongly agree } \\
\text { Agree } \\
\text { Neutral }\end{array}$ & $\begin{array}{l}12 \\
10 \\
3\end{array}$ & $\begin{array}{l}48 \\
40 \\
12\end{array}$ \\
\hline
\end{tabular}




\begin{tabular}{|c|c|c|c|c|}
\hline No & Information & Answer & Frequency & Percentage \\
\hline & $\begin{array}{l}\text { and video recording to } \\
\text { get responses from } \\
\text { peers and lecturer in } \\
\text { the WhatsApp group }\end{array}$ & & & \\
\hline 3 & $\begin{array}{l}\text { I have high } \\
\text { expectation to myself } \\
\text { when doing the audio } \\
\text { and video recording } \\
\text { through WhatsApp } \\
\text { group }\end{array}$ & $\begin{array}{l}\text { Strongly agree } \\
\text { Agree } \\
\text { Neutral }\end{array}$ & $\begin{array}{l}9 \\
14 \\
2\end{array}$ & $\begin{array}{l}36 \\
56 \\
8\end{array}$ \\
\hline 4 & $\begin{array}{l}\text { The WhatsApp group } \\
\text { set is for preparing me } \\
\text { improving my } \\
\text { speaking skills today } \\
\text { and future time }\end{array}$ & $\begin{array}{l}\text { Strongly agree } \\
\text { Agree } \\
\text { Neutral }\end{array}$ & $\begin{array}{l}14 \\
7 \\
4\end{array}$ & $\begin{array}{l}56 \\
28 \\
16\end{array}$ \\
\hline 5 & $\begin{array}{l}\text { I work best in a } \\
\text { WhatsApp group for } \\
\text { English speaking } \\
\text { environment }\end{array}$ & $\begin{array}{l}\text { Strongly agree } \\
\text { Agree } \\
\text { Neutral } \\
\text { Disagree }\end{array}$ & $\begin{array}{l}5 \\
12 \\
5 \\
3\end{array}$ & $\begin{array}{l}20 \\
48 \\
20 \\
12\end{array}$ \\
\hline 6 & $\begin{array}{l}\text { I speak whatever I } \\
\text { want to say in English } \\
\text { either through audio } \\
\text { recording my voice or } \\
\text { video recording in the } \\
\text { WhatsApp group }\end{array}$ & $\begin{array}{l}\text { Strongly agree } \\
\text { Agree } \\
\text { Neutral }\end{array}$ & $\begin{array}{l}2 \\
15 \\
8\end{array}$ & $\begin{array}{l}8 \\
60 \\
32\end{array}$ \\
\hline
\end{tabular}

Table 2 shows that students agreed and realized the importance of WhatsApp as the platform to practice speaking using audio and video recording. The sixth item of statement related to the intrinsic motivation of the need aspect. The highest percentage of asking their motivation was on the scale of agree. Students need a platform where they could interact, such in a natural way. This is in line with Awada \& Wang (2016) that the most important benefits of the WhatsApp application are its ability to improve communication within a group. Through audio and video recording, students felt free to express and respond to ideas from peers and lecturers in the WhatsApp group. 
Table 3

Motivation (Mastery Goal)

\begin{tabular}{|c|c|c|c|c|}
\hline No & Information & Answer & Frequency & Percentage \\
\hline 1 & $\begin{array}{l}\text { No matter how much I } \\
\text { like and dislike the } \\
\text { class and the rule set } \\
\text { for only speaking } \\
\text { English is allowed in } \\
\text { the WhatsApp group, } \\
\text { I still try to record my } \\
\text { voice both audio and } \\
\text { video recording }\end{array}$ & $\begin{array}{l}\text { Strongly agree } \\
\text { Agree } \\
\text { Neutral } \\
\text { Disagree }\end{array}$ & $\begin{array}{l}8 \\
10 \\
6 \\
1\end{array}$ & $\begin{array}{l}32 \\
40 \\
24 \\
4\end{array}$ \\
\hline 2 & $\begin{array}{l}\text { I feel that challenging } \\
\text { assignments in the } \\
\text { WhatsApp group can } \\
\text { be a great speaking } \\
\text { learning experience }\end{array}$ & $\begin{array}{l}\text { Strongly agree } \\
\text { Agree }\end{array}$ & $\begin{array}{l}17 \\
8\end{array}$ & $\begin{array}{l}68 \\
32\end{array}$ \\
\hline 3 & $\begin{array}{l}\text { My friends help me to } \\
\text { gain valuable } \\
\text { knowledge in the } \\
\text { WhatsApp group } \\
\text { speaking learning } \\
\text { environment }\end{array}$ & $\begin{array}{l}\text { Strongly agree } \\
\text { Agree } \\
\text { Neutral } \\
\text { Disagree }\end{array}$ & $\begin{array}{l}11 \\
10 \\
3 \\
1\end{array}$ & $\begin{array}{l}44 \\
40 \\
12 \\
4\end{array}$ \\
\hline 4 & $\begin{array}{l}\text { My speaking quality } \\
\text { performance both } \\
\text { audio and video } \\
\text { recording in the } \\
\text { WhatsApp group is } \\
\text { independent }\end{array}$ & $\begin{array}{l}\text { Strongly agree } \\
\text { Agree } \\
\text { Neutral }\end{array}$ & $\begin{array}{l}6 \\
10 \\
9\end{array}$ & $\begin{array}{l}24 \\
40 \\
36\end{array}$ \\
\hline 5 & $\begin{array}{l}\text { I do more than I have } \\
\text { to for a speaking } \\
\text { assignment assigned } \\
\text { in the WhatsApp } \\
\text { group to help me } \\
\text { understand the } \\
\text { speaking materials, } \\
\text { instructions, and } \\
\text { activities better }\end{array}$ & $\begin{array}{l}\text { Strongly agree } \\
\text { Agree } \\
\text { Neutral } \\
\text { Disagree }\end{array}$ & $\begin{array}{l}9 \\
11 \\
4 \\
1\end{array}$ & $\begin{array}{l}36 \\
44 \\
16 \\
4\end{array}$ \\
\hline 6 & $\begin{array}{l}\text { I enjoy learning daily } \\
\text { conversation through } \\
\text { WhatsApp group by } \\
\text { audio and video } \\
\text { recording my voice } \\
\text { and get responses }\end{array}$ & $\begin{array}{l}\text { Strongly agree } \\
\text { Agree } \\
\text { Neutral }\end{array}$ & $\begin{array}{l}12 \\
10 \\
3\end{array}$ & $\begin{array}{l}48 \\
40 \\
12\end{array}$ \\
\hline
\end{tabular}




\begin{tabular}{|c|c|c|c|c|}
\hline No & Information & Answer & Frequency & Percentage \\
\hline 7 & $\begin{array}{l}\text { from the group } \\
\text { members } \\
\text { I try to do my best } \\
\text { when I was assigned } \\
\text { to audio and video } \\
\text { recording my voice in } \\
\text { the form of small } \\
\text { interview with my } \\
\text { pair, group work, role } \\
\text { play, short } \\
\text { demonstration, and } \\
\text { individual speaking } \\
\text { tasks in the WhatsApp } \\
\text { group }\end{array}$ & $\begin{array}{l}\text { Strongly agree } \\
\text { Agree } \\
\text { Neutral }\end{array}$ & $\begin{array}{l}15 \\
7 \\
3\end{array}$ & $\begin{array}{l}60 \\
28 \\
12\end{array}$ \\
\hline
\end{tabular}

Table 3 describes that students were some strongly disagree, and some others agree in the aspect of mastery goal of intrinsic motivation. They showed their inner motivation in order to achieve something they enjoy to do, for instance, do some recording to speak daily conversation to get responses from the WhatsApp group members. Lecturer also took apart to strengthen stimulating students' motivation to speak actively, for example, assigned students with challenging tasks like video recording their cooking demonstration and sharing the video for feedback and responses from WhatsApp group members. Afful and Akrong (2019) argue that the creation of a user group on WhatsApp to provide a platform for lecturers to share lecture materials, other digital information, and alert services related to academics. They considered that the use of WhatsApp has a positive effect on the academic performance of students so long as the dominant use is to study-related purposes.

\section{Table 4}

Motivation (Fear)

\begin{tabular}{lllll}
\hline No & Information & Answer & Frequency & Percentage \\
\hline 1 & I feel no worries in & Strongly agree & 8 & 32 \\
& speaking English in & Agree & 6 & 24 \\
& the WhatsApp group & $\begin{array}{l}\text { Neutral } \\
\text { Disagree }\end{array}$ & 10 & 40 \\
& & & & 4 \\
2 & I enjoy challenging & Strongly agree & 13 & 52 \\
& tasks for audio and & Agree & 9 & 36 \\
& video recording in the & Neutral & 3 & 12 \\
\hline & WhatsApp group such & & & \\
\hline
\end{tabular}




\begin{tabular}{|c|c|c|c|c|}
\hline No & Information & Answer & Frequency & Percentage \\
\hline & $\begin{array}{l}\text { as small interview } \\
\text { with friends, role } \\
\text { plays, demonstration } \\
\text { activities, group work, } \\
\text { and individual } \\
\text { assignment }\end{array}$ & & & \\
\hline \multirow[t]{4}{*}{3} & I am not nervous & Strongly agree & 3 & 12 \\
\hline & when doing audio and & Agree & 9 & 36 \\
\hline & video recording in the & Neutral & 9 & 36 \\
\hline & WhatsApp group & Disagree & 4 & 16 \\
\hline \multirow[t]{6}{*}{4} & I feel ashamed when & Strongly agree & 1 & 4 \\
\hline & my lecturer gives & Agree & 7 & 28 \\
\hline & correction on my & Neutral & 8 & 32 \\
\hline & audio and video & Disagree & 5 & 20 \\
\hline & recording in the & Strongly & 4 & 16 \\
\hline & WhatsApp group & disagree & & \\
\hline
\end{tabular}

Fourth items of the statement described most of the students in this study agreed that they felt no doubt to speak English since they enjoyed speaking tasks given for every week, such as did a short interview, pair wok, and group work. In addition, they felt not nervous and ashamed for audio and video recording to get connected and interacted with their peers and lecturer within the college hours and at home throughout the WhatsApp group. This is in line with Beckman (2010), who stated that mobile technologies offer chances to continue access education from distance that can be pursued off-campus and transnationally with the same peercentered approaches available on-campus, engaging authenticity of both content and context as well as offer discussion spaces.

\section{Table 5}

Motivation (Authority Expectation)

\begin{tabular}{lllll}
\hline No & Information & Answer & Frequency & Percentage \\
\hline 1 & I feel that I should be & Strongly agree & 4 & 16 \\
& $\begin{array}{l}\text { recognized when I } \\
\text { audio and video }\end{array}$ & Agree & 9 & 36 \\
& $\begin{array}{l}\text { Necotral } \\
\text { recording in the }\end{array}$ & Disagree & 11 & 44 \\
& WhatsApp group & & & 4 \\
2 & $\begin{array}{l}\text { I try to live up my } \\
\text { presence to what my }\end{array}$ & Strongly agree & 9 & \\
& lecturer expects me in & Neutral & 9 & 37.5 \\
& & & 67.5 \\
\hline
\end{tabular}




\begin{tabular}{|c|c|c|c|c|}
\hline No & Information & Answer & Frequency & Percentage \\
\hline 3 & $\begin{array}{l}\text { the classroom and in } \\
\text { the WhatsApp group } \\
\text { When I make } \\
\text { mistakes in the } \\
\text { aspects of } \\
\text { pronunciation, } \\
\text { grammar, vocabulary, } \\
\text { fluency, and accuracy } \\
\text { in audio and video } \\
\text { recording in the } \\
\text { WhatsApp group, I } \\
\text { feel that I let my } \\
\text { lecturer down }\end{array}$ & $\begin{array}{l}\text { Strongly agree } \\
\text { Agree } \\
\text { Neutral } \\
\text { Disagree } \\
\text { Strongly } \\
\text { disagree }\end{array}$ & $\begin{array}{l}3 \\
13 \\
1 \\
5 \\
2\end{array}$ & $\begin{array}{l}12.5 \\
54.2 \\
1.4 \\
20.8 \\
8.3\end{array}$ \\
\hline 4 & $\begin{array}{l}\text { It is important to } \\
\text { speak day to day } \\
\text { English speaking } \\
\text { through WhatsApp } \\
\text { group such the way } \\
\text { my Basic speaking } \\
\text { lecturer wants }\end{array}$ & $\begin{array}{l}\text { Strongly agree } \\
\text { Agree } \\
\text { Neutral }\end{array}$ & $\begin{array}{l}12 \\
11 \\
1\end{array}$ & $\begin{array}{l}50 \\
45.8 \\
4.2\end{array}$ \\
\hline 5 & $\begin{array}{l}\text { I have no problem } \\
\text { telling my peers and } \\
\text { lecturer in the } \\
\text { WhatsApp group that } \\
\text { I made some mistakes } \\
\text { in English speaking }\end{array}$ & $\begin{array}{l}\text { Strongly agree } \\
\text { Agree } \\
\text { Neutral } \\
\text { Disagree } \\
\text { Strongly } \\
\text { disagree }\end{array}$ & $\begin{array}{l}7 \\
10 \\
5 \\
1 \\
1\end{array}$ & $\begin{array}{l}29.2 \\
41.7 \\
20.8 \\
4.2 \\
4.2\end{array}$ \\
\hline 6 & $\begin{array}{l}\text { I can speak English } \\
\text { by audio and video } \\
\text { recording in the } \\
\text { WhatsApp group from } \\
\text { day to day in the } \\
\text { semester period and I } \\
\text { finally I find myself is } \\
\text { able to speak English } \\
\text { well }\end{array}$ & $\begin{array}{l}\text { Strongly agree } \\
\text { Agree } \\
\text { Neutral } \\
\text { Disagree }\end{array}$ & $\begin{array}{l}5 \\
7 \\
11 \\
1\end{array}$ & $\begin{array}{l}20.8 \\
29.2 \\
45.8 \\
4.2\end{array}$ \\
\hline
\end{tabular}

Table 5 describes extrinsic motivation in the aspect of authority expectation to peers and lecturer in the WhatsApp group for speaking connection, collaboration, and communication for daily conversation. Students mostly strongly agreed and agreed that they really paid attention and appreciated the role of their lecturer and peers in supporting them to be able to speak English in a semester. It is in relation to the study conducted by Bouhnik and Deshen (2014) that they asserted that the WhatsApp group the learners used improved 
interaction, promoted the social atmosphere, fostered dialog, increased sharing among learners, and created an enjoyable atmosphere and a profound collaboration with peers.

Table 6

Self-confidence

\begin{tabular}{|c|c|c|c|c|}
\hline No & Information & Answer & Frequency & Percentage \\
\hline 1 & $\begin{array}{l}\text { Speaking English via } \\
\text { audio and video } \\
\text { recording in the } \\
\text { WhatsApp group is } \\
\text { easy and fun }\end{array}$ & $\begin{array}{l}\text { Strongly agree } \\
\text { Agree } \\
\text { Neutral }\end{array}$ & $\begin{array}{l}10 \\
10 \\
4\end{array}$ & $\begin{array}{l}41.7 \\
41.7 \\
16.7\end{array}$ \\
\hline 2 & $\begin{array}{l}\text { I can tell in English } \\
\text { whatever I want to tell } \\
\text { to my friends and my } \\
\text { lecturer by audio and } \\
\text { video recording in the } \\
\text { WhatsApp group } \\
\text { without any worries } \\
\text { of speaking mistakes }\end{array}$ & $\begin{array}{l}\text { Strongly agree } \\
\text { Agree } \\
\text { Neutral } \\
\text { Disagree }\end{array}$ & $\begin{array}{l}5 \\
5 \\
11 \\
3\end{array}$ & $\begin{array}{l}20.8 \\
20.8 \\
45.8 \\
12.5\end{array}$ \\
\hline 3 & $\begin{array}{l}\text { I feel excited learning } \\
\text { daily conversation in } \\
\text { the WhatsApp group } \\
\text { by audio and video } \\
\text { recording }\end{array}$ & $\begin{array}{l}\text { Strongly agree } \\
\text { Agree } \\
\text { Neutral }\end{array}$ & $\begin{array}{l}11 \\
9 \\
4\end{array}$ & $\begin{array}{l}45.8 \\
37.5 \\
16.7\end{array}$ \\
\hline 4 & $\begin{array}{l}\text { I feel satisfied with } \\
\text { my speaking } \\
\text { performance in the } \\
\text { form of role play, } \\
\text { small interview, and } \\
\text { individual tasks } \\
\text { during a semester } \\
\text { period of teaching and } \\
\text { learning via } \\
\text { WhatsApp help as the } \\
\text { media to practice } \\
\text { speaking English }\end{array}$ & $\begin{array}{l}\text { Strongly agree } \\
\text { Agree } \\
\text { Neutral }\end{array}$ & $\begin{array}{l}10 \\
8 \\
6\end{array}$ & $\begin{array}{l}41.7 \\
33.3 \\
25\end{array}$ \\
\hline 5 & $\begin{array}{l}\text { I feel satisfied with } \\
\text { my English } \\
\text { vocabularies } \\
\text { improvement when } \\
\text { speaking from day to } \\
\text { day audio and video }\end{array}$ & $\begin{array}{l}\text { Strongly agree } \\
\text { Agree } \\
\text { Neutral }\end{array}$ & $\begin{array}{l}9 \\
7 \\
8\end{array}$ & $\begin{array}{l}37.5 \\
29.2 \\
33.3\end{array}$ \\
\hline
\end{tabular}




\begin{tabular}{lllll}
\hline No & Information & Answer & Frequency & Percentage \\
\hline \multirow{2}{*}{$\begin{array}{l}\text { recording in the } \\
\text { WhatsApp group }\end{array}$} & & & \\
6 & & & \\
I can pronounce & Strongly agree & 6 & 24 \\
& English words better & Agree & 12 & 48 \\
from day to day audio & Neutral & 6 & 24 \\
and video recording in & Disagree & 1 & 4 \\
the WhatsApp group & & & \\
7 & & & 4 \\
I feel my grammar in & Strongly agree & 1 & 49 \\
speaking English via & Agree & 10 & 36 \\
day to day audio and & Neutral & 9 & 20 \\
video recording in the & Disagree & 5 & \\
$\begin{array}{l}\text { WhatsApp group is in } \\
\text { the well-ordered }\end{array}$ & & & \\
\hline
\end{tabular}

Table 6 describes how students perceived that they agreed and showed ability from day to day to speak confidently using audio and video recording in the WhatsApp group. They felt themselves in a semester from not confident enough to high confidence. They could correct their own mistakes in pronouncing daily English words, grammar, and were satisfied with the progress they performed in a semester.

\section{Conclusion}

This paper highlights the potential that WhatsApp recording chat-based in stimulating students' self-confidence and motivation in speaking daily conversation in order to familiarize own self producing English sentences. It demonstrates the importance of applying mobile learning to support and engage the teaching and learning attractively and enjoyably. The results revealed that students showed progress from day to day, speaking through WhatsApp. They also took advantage of this implementation as a habit. Besides, there was no fear of making mistakes and felt encouraged as a daily connection, collaboration, and communication need. Students with low self-confidence and motivation were also engaged with the help and inspiration coming from peers and lecturer as WhatsApp group members. This kind of mobile learning is best to be leveraged to supplement conventional teaching and learning. Therefore, the results contribute to advancing mobile research in refining both theory and implementation for more stimulation in motivating and increasing self-confidence. 


\section{References}

Afful, B \& Akrong, R. (2019). WhatsApp and academic performance among undergraduate students in Ghana: Evidence from the University of Cape Coast. Journal of Education for Business, DOI: 10.1080/08832323.2019.1644276

Alshammari, R., Parkes, M., \& Adlington, R. (2017). Using WhatsApp in EFL Instruction with Saudi Arabian University Students. Arab World English Journal, 8 (4). DOI: https://dx.doi.org/10.24093/awej/vol8no4.5

Andrews, T., Dyson, L.E., \& Wishart, J. (2015). Advancing ethics frameworks and scenariobased learning to support educational research into mobile learning. International Journal of Research \& Method in Education, 38:3, 320334, DOI: $\underline{10.1080 / 1743727 X .2015 .1026252}$

Andujar, A \& Salaberri-Ramiro, M.S. (2019). Exploring chat-based communication in the EFL class: computer and mobile environments. Computer Assisted Language Learning, DOI: 10.1080/09588221.2019.1614632

Awada, G \& Wang, S. (2016). Effect of WhatsApp on critique writing proficiency and perceptions toward learning. Cogent Education, 3:1, DOI: 10.1080/2331186X.2016.1264173

Beckmann, E.A. (2010). Learners on the move: mobile modalities in development studies. Distance Education, 31:2, 159-173, DOI: 10.1080/01587919.2010.498081

Bocconi, S \& Trentin, G. (2014). Modelling blended solutions for higher education: teaching, learning, and assessment in the network and mobile technology era. Educational Research and Evaluation, 20:7-8, 516-535, DOI: 10.1080/13803611.2014.996367

Bouhnik, D., \& Deshen, M. (2014). WhatsApp goes to school: Mobile instant messaging between teachers and students. Journal of Information Technology Education: Research, 13, 217-231.

Boyinbode, O., Bagula, A., \& Ngambi, D. (2011). An opencast mobile learning framework for enhancing learning in higher education. International Journal of $u$ - and $e$-Service, Science and Technology, 4, 11-18.

Campbell, A. (2019). Design-based research principles for successful peer tutoring on social media. International Journal of Mathematical Education in Science and Technology, 50:7, 1024-1036, DOI: 10.1080/0020739X.2019.1650306 
Castrillo, M. D. Bárcena, E., \& Martín Monje, E. (2014). New forms of negotiating meaning on the move: The use of mobile-based chatting for foreign language distance learning. IADIS International Journal on WWW/Internet, 12(2), 51-67.

Fuente, M.J.D.L. (2014). Learners' attention to input during focus on form listening tasks: The role of mobile technology in the second language classroom. Computer Assisted Language Learning, 27(3), 261-276.

Godwin-Jones, R. (2017). Smartphones and language learning. Language Learning \& Technology, 21(2), 3-17. Retrieved from

Hamad, M.M. (2017). Using WhatsApp to enhance students' learning of English language “experience to share". Higher Education Studies, 7(4). http://doi.org/10.5539/hes.v7n4p74

Huang, C. S. J., Yang, S. J. H., Chiang, T. H. C., \& Su, A. Y. S. (2016). Effects of situated mobile learning approach on learning motivation and performance of EFL students. Educational Technology and Society, 19(1), 263-276.

Husbye, N.E \& Elsener, A.A. (2013). To Move Forward, We Must Be Mobile. Journal of Digital Learning in Teacher Education, 30:2, 4651, DOI: $\underline{10.1080 / 21532974.2013 .10784726}$

Johnson, R. B., Onwuegbuzie, A. J., \& Turner, L. A. (2007). Toward a definition of mixed methods research. Journal of Mixed Methods Research, 1(2), 112-133. doi: $10.1177 / 1558689806298224$

Kim, D., Rueckert, D., Kim, D.J., \& Seo, D. (2013). Students' perceptions and experiences of mobile learning. Language Learning \&Technology, 17(3), 52-73.

Ma, Q. (2017). A multi-case study of university students' language-learning experience mediated by mobile technologies: a socio-cultural perspective. Computer Assisted Language Learning, 30:3-4, 183-203, DOI: 10.1080/09588221.2017.1301957

Madge, C., Breines, M.R., Dalu, M.T.B., Gunter, A., Mittelmeier, J., Prinsloo, P., \& Raghuram, P. (2019). WhatsApp use among African international distance education (IDE) students: transferring, translating and transforming educational experiences. Learning, Media and Technology, 44:3, 267-282, DOI: 10.1080/17439884.2019.1628048 
Maming, K. (2018). Helping the EFL learners in reading class: learning by interacting with social media-related topics through pre-question way. Asian EFL Journal, 10(11), p. 205-223. Retrieved from https://www.asian-efl-journal.com/wpcontent/uploads/AEFLJ-Volume-20-Issue-11-November-2018.pdf

Li, K.C., Lee, L.Yin-Kin., Wong, Suet-Lai., Yau, I.Sui-Yu \& Wong, B.TakMing. (2018). Effects of mobile apps for nursing students: learning motivation, social interaction and study performance. Open Learning: The Journal of Open, Distance and e-Learning, 33:2, 99-114, DOI: 10.1080/02680513.2018.1454832

Plana, M. G. C., Escofet, M. I. G., Figueras, I. T., Gimeno, A., Appel, C., \& Hopkins, J. (2013). Improving learners' reading skills through instant short messages: A sample study using WhatsApp. In Proceeding of WorldCall 2013-Call: Sustainability and ComputerAssisted Language Learning (pp. 80-84). Glasgow, UK: University of Ulster.

Rambe, P., \& Bere, A. (2013). Using mobile instant messaging to leverage learner participation and transform pedagogy at a South African University of Technology. British Journal of Educational Technology, 44(4), 544-561.

Rodriguez, J. E. (2011). Social media use in higher education: Key areas to consider for educators. Journal of Online Learning and Teaching, 7(4).

Sakkir, G. (2018). Interest and writing skill of the university students on using social mediaFacebook in writing class. Asian EFL Journal, 20(5). Retrieved from https://www.asian-efl-journal.com/wp-content/uploads/AEFLJ-Volume-20-Issue-5May-2018.pdf

Shia, R.M. (2014). academic intrinsic and extrinsic motivation and metacognition. Education Technology, 1-20. Retrieved from https://www.slideshare.net/mizah16/assessingacademic-intrinsic-motivation

Simone, D \& Cosimo, G. (2016). Mobile learning: Extreme outcomes of: "everywhere, anytime.” ERIC retrieved from https://eric.ed.gov/?id=ED571440

Statista. (2019). Most popular global mobile messenger apps as of July 2019, based on number of monthly active users (in millions). Retrieved from https://www.statista.com/statistics/258749/most-popular-global-mobile-messengerapps/ 
Stockwell, G. (2010). Using mobile phones for vocabulary activities: Examining the effect of platform. Language Learning \& Technology, 14(2), 95-110.

Sweeney, P., \& Moore, C. (2012). Mobile apps for learning vocabulary: Categories, evaluation and design for teachers and developers. International Journal of Computer-Assisted Language Learning and Teaching, 2(4), 1-16.

Tài, P.T. (2016). An investigation into some factors influencing to student's motivation to learn speaking English of the first - year students at English department, University of Foreign Language Studies - Danang University - Vietnam. Asian EFL Journal, (4), p. 177-182. TESOL Indonesia International Conference Edition. Retrieved from https://www.asian-efl-journal.com/wp-content/uploads/AEJ-Special-EditionDecember-2016-TESOL-Indonesia-Conference-Volume-4.pdf

Timmis, S. (2012). Constant companions: Instant messaging conversations as sustainable supportive study structures amongst undergraduate peers. Computers \& Education, 59(1), 3-18.

Xu, Q., \& Peng, H. (2017). Investigating mobile-assisted oral feedback in teaching Chinese as a second language. Computer Assisted Language Learning, 30(3-4), 173-182

Zhang, H., Song, W., \& Burston, J. (2011). Reexamining the effectiveness of vocabulary learning via mobile phones. The Turkish Online Journal of Educational Technology, 10(3), 203-214.

Zou, B., \& Yan, X.X. (2014). Chinese students' perceptions of using mobile devices for English learning. International Journal of Computer-Assisted Language Learning and Teaching, 4(3), 20-33. 